\title{
Study of the Initial Corrosion of X80 Steel in a Saturated Saline Soil Co-Contaminated with $\mathrm{Cl}^{-}, \mathrm{SO}_{4}{ }^{2-}$ and $\mathrm{HCO}_{3}{ }^{-}$
}

\author{
Fuli Ma ${ }^{1}$, Ruizhen Xie ${ }^{1}$, Pengju Han ${ }^{1,2, *}$, Xiaohong Bai ${ }^{1, *}$ \\ ${ }^{1}$ Department of Civil Engineering, Taiyuan University of Technology, Taiyuan, 030024, P. R. China \\ ${ }^{2}$ State Key Laboratory of Hydraulic Engineering Simulation and Safety, Tianjin University, Tianjin, \\ 300350, P. R. China \\ *E-mail: 13834569544@163.com, bxhong@tyut.edu.cn
}

doi: $10.20964 / 2018.06 .33$

Received: 5 January 2018 / Accepted: 30 March 2018 / Published: 10 May 2018

\begin{abstract}
An orthogonal experimental group of saline soils with soluble salt anions $\left(\mathrm{Cl}^{-}, \mathrm{SO}_{4}{ }^{2-}\right.$ and $\left.\mathrm{HCO}_{3}{ }^{-}\right)$was designed by orthogonal assistant and IBM SPSS statistics 21 software. The initial dynamic potentiodynamic polarization of X80 steel embedded in different saline soils was tested using a threeelectrode system. The statistical range and variance in the measurement data, the corrosion morphologies and composition of the X80 steel and the corrosion mechanism were analysed. The results show that the corrosion of X80 steel in S9 was the weakest, and the corrosion current density reached 4.9E-7. The corrosive behaviour of X80 steel in different saline soils exhibited the following order: $\mathrm{S} 9<\mathrm{S} 6<\mathrm{S} 3<\mathrm{S} 4<\mathrm{S} 5<\mathrm{S} 8<\mathrm{S} 2<\mathrm{S} 7<\mathrm{S} 1$. The $\mathrm{SO}_{4}{ }^{2-}$ anions mainly affected the corrosion potential, and $\mathrm{Cl}^{-}$and $\mathrm{HCO}_{3}{ }^{-}$mainly affected the corrosion current density. The optimal contents of $\mathrm{Cl}^{-}, \mathrm{SO}_{4}{ }^{2-}$ and $\mathrm{HCO}_{3}{ }^{-}$in sandy soil are $1,0.3$, and $0.3 \mathrm{mmol} / 100 \mathrm{~g}$ for the $R_{\mathrm{p}}$, respectively. The initial corrosion of $\mathrm{X} 80$ steel in different saline soils was weak, and mainly exhibited local pitting. $\mathrm{SO}_{4}{ }^{2-}$ is the most important factor affecting the initial corrosion behaviour of the $\mathrm{X} 80$ steel. The $\mathrm{Cl}^{-}, \mathrm{SO}_{4}{ }^{2-}$ and $\mathrm{HCO}_{3}{ }^{-}$ factors were not statistically significant $(\mathrm{P}>0.05)$, which may be due to the level selection of the experimental factors.
\end{abstract}

Keywords: soluble salt anion; X80 steel; corrosion; orthogonal assistant; IBM SPSS statistics 21

\section{$\underline{\text { FULL TEXT }}$}

(C) 2018 The Authors. Published by ESG (www.electrochemsci.org). This article is an open access article distributed under the terms and conditions of the Creative Commons Attribution license (http://creativecommons.org/licenses/by/4.0/). 